\title{
Glacier extent and sea level variation during the Late Weichselian on northwest Spitsbergen
}

\author{
SCOTT J. LEHMAN AND STEVEN L. FORMAN
}

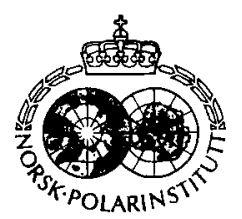

Lehman, S. J. \& Forman, S. L. 1987: Glacier extent and sea level variation during the Late Weichselian on northwest Spitsbergen. Polar Research 5 n.s., 271-272.

Scott J. Lehman" and Steven L. Forman, Institute of Arctic and Alpine Research, University of Colorado, Boulder CO 80309, U.S.A. "Present address: Woods Hole Oceanographic Institution, Woods Hole MA 02543, U.S.A.

The nature and timing of the last glaciation in the SvalbardBarents Shelf region has been a major source of debate for the last century. Presently, the results of most glacial geologic investigations along the west coast of Spitsbergen suggest a diminutive Late Weichselian glaciation in that area - an argument that rests primarily on the occasional occurrences of ice limit features and on the widespread distribution of well preserved pre-Late Weichselian raised marine terraces. Proponents of more extensive Late Weichselian ice cover rest their case on: 1) the magnitude of postglacial uplift in the area, which reaches $60 \mathrm{~m}$ on some headlands and more than $100 \mathrm{~m}$ near the center of the archipelago (Salvigsen unpublished), 2) on the possibility that pre-Late Weichselian beaches might survive coverage by cold-based ice and 3 ) on the further possibility that ice limit features may record former grounding lines within fjords instead of former ice margins. Because of this controversy, we present a large body of new uplift data that we believe is only compatible with restricted Late Weichselian glaciation of west Spitsbergen, and that is suggestive of larger ice loads to the east. This loading may have been confined to the eastern part of the archipelago, or related to a possible Barents Shelf Ice Sheet.

Late Weichselian marine limit (LWML) isobases for the north and west coasts of Spitsbergen are shown in Fig. 1 along with features interpreted as Late Weichselian ice limits (shading and arrows). All elevations, except those constraining the $90 \mathrm{~m}$ isoline, were obtained from marine terraces lying beyond what we regard as Late Weichselian ice limits and are therefore considered time-synchronous. The strandline tilt of the marine limit between a and $\mathrm{a}^{\prime}$ is $0.75 \mathrm{~m} / \mathrm{km}$ and is $1.0 \mathrm{~m} / \mathrm{km}$ between $a^{\prime}$ and $a^{\prime \prime}$ (Lehman 1987). The latter number probably underestimates the actual time synchronous tilt if the $90 \mathrm{~m}$ isobase is significantly younger than the regional LWML. In the northwest the marine limit drops to $0 \mathrm{~m}$ even though this area was subject to loading by an ice dome centered near Hornemantoppen (e.g. Salvigsen \& Österholm 1982). This suggests that in some areas local ice margins may be unrelated to the regional isostatic signal. In the Forlandsund area (b- $\left.b^{\prime}\right)$ tilts similar in magnitude to those determined in the north are oriented roughly east-west (Forman 1986), also with no hint of levelling towards the east. Such large strandline tilts are not compatible with a continuous ice margin reaching the shelf break. The data suggest that the center of ice-loading was to the east of W. Spitsbergen and that little loading was sustained along the west coast itself.

Uplift curves from the west coast (Forman et al. 1987) suggest that emergence (deglaciation) commenced slowly around $13 \mathrm{ka}$
B.P. and became rapid around $9.5 \mathrm{ka} \mathrm{B.P.} \mathrm{when} \mathrm{thermophilous}$ mollusc taxa entered the area. The initiation of deglaciation appears to correspond with the first evidence of Late Weichselian amelioration in the Norwegian Sea (Jansen \& Bjørklund

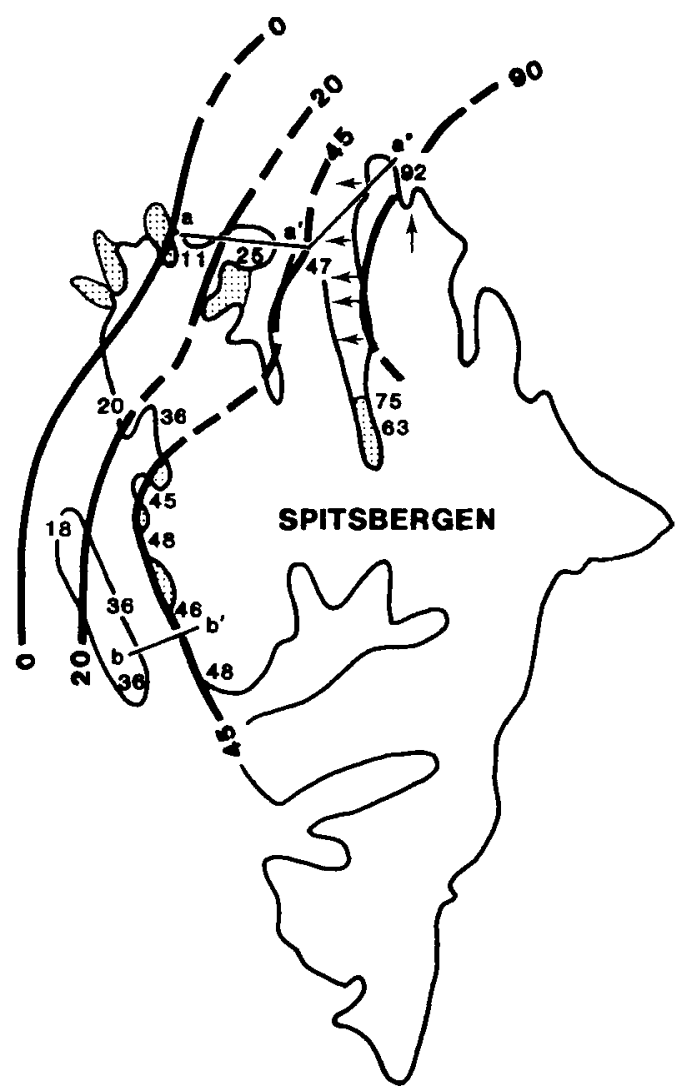

Fig. 1. Late Weichselian marine limit (LWML) isobases and Late Weichselian ice limits for the north and west coasts of Spitsbergen. 
1985) and the later, more rapid phase of deglaciation, with the Holocene migration of the polar front through the Norwegian Sea.

\section{References}

Forman, S. L. 1986: Quaternary glacial, marine and soil developmental history of the Forlandsund area, Western Spitsbergen, Svalbard. Univ. of Colorado unpubl. Ph.D. thesis.
Forman, S. L., Mann, D. H. \& Miller, G. H. 1987: Late Weichselian and Holocene relative sea-level history of Brøggerhalvøya, Spitsbergen. Quaternary Research 27, 41-50.

Jansen, E. \& Bjørklund, K. 1985: Surface ocean circulation in the Norwegian Sea 15,000 years B.P. to present. Boreas 14, 243-258.

Lehman, S. J. 1987: Late Quaternary paleo-environments of western and northern Spitsbergen, Sualbard. Univ. of Colorado unpubl. Ph.D. thesis.

Salvigsen, O \& Österholm, H. 1982: Radiocarbon dated raised beaches and glacial history of the northern coast of Spitsbergen, Svalbard. Polar Research $1,97-115$. 